\section{The College Library}

The Librarian would like to thank those Members of the College who so very generously donated copies of their works to the College Library. Books have recently been received from the following:

Dr A. Bentovim Child Sexual Abuse in the Family and Related Papers

Dr A. Daniels Fool or Physician: Memoirs of $a$ Sceptical Doctor

Dr M. Faulk Basic Forensic Psychiatry

Professor H. Freeman The Treatment of Mental Disorders in the Community; The Future of Pharmacotherapy New Drug Delivery Systems

Dr J. Gold The Psychiatric Implications of Menstruation

Dr H. P. Greenberg Handbook of Neuropsychological Assessment

Dr N. Holden Examination Techniques in Psychiatry

Dr L. Iverson Cognitive Neurochemistry

Dr D. F. Klein Anxiety
Professor M. Lader The Patterns of Improvement in Depressed In-Patients

Professor W. A. Lishman Organic Psychiatry

Dr P. Lomas The Limits of Interpretation

Dr M. J. Pritchard Medicine and the Behavioural Sciences

Dr J. D. Pollitt Psychiatric Emergencies in Family Practice

Professor W. L. Rees A New Short Textbook of Psychiatry

Professor B. Sacks The Adolescent with Down's Syndrome

Professor A. C. P. Sims Symptoms of the Mind: An Introduction to Descriptive Psychopathology

Dr D. A. Spencer Report on Meanwood Park Hospital

Dr G. J. Taylor Psychosomatic Medicine and Contemporary Psychoanalysis

Dr C. Thompson The Origins of Modern Psychiatry

Dr M. R. Trimble Biological Psychiatry

\title{
Obituary
}

\section{Editor: Henry R. Rollin}

GHULAM ALI ASGHAR, Medical Director, Asghar Hospital, Karachi, Pakistan.

Dr Asghar died at the age of 75. He was a distinguished Pakistani psychiatrist and a Foundation Fellow of the College.

He was born on 16 July 1912 in a small village near Layalpur, Punjab, Pakistan. He was educated at a local school and subsequently graduated from Amritsar Medical School in India.

On leaving Medical School he joined the Railway Medical Services, but when World War II erupted he joined the Army Medical Service, achieving the rank of Captain. It was during a stay at an army camp at Ranchi, located near the mental hospital, that he started to take an interest in psychiatry. He subsequently joined the staff of Ranchi Mental Hospital and was later transferred to Lahore Mental Hospital.

He decided to further his studies in England and joined Dr Arthur Oldham's firm at Cane Hill Hospital, Coulsdon. He took a part in the establishment of an ECT unit and took a great interest in other physi- cal methods of treatment in psychiatry, including insulin therapy. He took part in a trial of the newly established phenothiazine, chlorpromazine (Largactil), and together with Dr William Sargant monitored the side effects of the drug to be seen in some patients exposed to direct sunlight.

On a second visit to England he obtained the DPM, after which he returned to resume charge as Physician Superintendent of Hyderabad Mental Hospital.

On leaving this hospital he went into private practice in Karachi and established his own private psychiatric hospital serving the local community and patients from all over Pakistan.

He held the posts of Associate Professor of Psychiatry at F.J. Medical School, Liquet Medical School and Dow Medical College Karachi. He was active in the Karachi Mental Health Foundation and was its Honorary Founder President and was an active and respected member of Pakistan Psychiatric Society. He welcomed the opportunity of attending 